\title{
Articles
}

\section{Key Strengths of an Innovative Volunteer Training Workshop}

\author{
Angelika Sellick, Vancouver \\ Monique Bournot-Trites, Ken Reeder, Andrew Scales, Mark Smith, and \\ Sandra Zappa-Hollman, University of British Columbia
}

\section{Acknowledgements}

Funding for this study was provided by the Canadian Association for University Continuing Education (CAUCE) in a grant to Scales, Bournot-Trites, Reeder, and Zappa-Hollman, and by Continuing Studies, the University of British Columbia, in a grant to Scales. The study has been conducted by the UBC Centre for Intercultural Language Studies (CILS) Research Committee with the kind collaboration of a staff member at UBC's Learning Exchange.

\begin{abstract}
Since 2004, the Learning Exchange of the University of British Columbia has hosted an award-winning ESL Conversation Program Facilitators Training Workshop. The workshop is designed to develop the skills of Vancouver's Downtown Eastside community members to lead local English conversation classes and contribute to civil society, and to support confidence and capacity building for the participants. The article reports on the key strengths of this innovative volunteer training program and addresses the first of the study's two research questions: What are the perceived strengths of the ESL Conversation Program
\end{abstract}

\section{RÉSumÉ}

Depuis 2004, le Learning Exchange de l’Université de la Colombie-Britannique est l'hôte d'un atelier de formation primé, destiné aux animateurs de programmes de conversation en anglais langue seconde. L'atelier est conçu pour développer les compétences des membres de la communauté du quartier Downtown Eastside de Vancouver à offrir des cours locaux de conversation anglaise et contribuer à la société civile, et favoriser le renforcement de la confiance et des capacités des participants. L'article présente les principaux atouts de ce programme innovateur de formation de bénévoles et adresse la première des deux

Canadian Journal of University Continuing Education / Vol. 37, No. 2, fall 2011

Revue Canadienne de L'Éducation Permanente Universitaire / Vol. 37, № 2, automne 2011

http://ejournals.library.ualberta.calindex.php/cjuce-rcepu 
Facilitators Training Workshop? The study involved 14 volunteer facilitators, four UBC staff members, and the researcher as participant; the data collected were observation notes, questionnaires, results from focus groups, and interviews. The study revealed that the key strengths of the training workshop lay in its approach to training, its focus on confidence and capacity building, the appreciation and contribution of volunteers' assets, and the support of the sponsoring university. The article concludes with a consideration of the implications for strategic planning for university-community engagement and replication of the program in other educational contexts. questions que pose l'étude: Quels sont les forces perçues de l'atelier de formation des animateurs du programme de conversation en anglais langue seconde? L'étude comprenait 14 animateurs bénévoles, 4 membres du personnel de l'UBC et le chercheur en tant que participant; les données recueillies sont venues de notes d'observation, de questionnaires, de résultats de groupes de discussion et d'entrevues. L'étude a révélé que les points forts de l'atelier de formation résident dans son approche à la formation, l'accent mis sur le renforcement de la confiance et des capacités, l'appréciation et la contribution des atouts des bénévoles et le soutien de l'université parrainante. L'article conclut en considérant les implications pour la planification stratégique de l'engagement universitaire-communautaire et l'application du programme dans d'autres contextes éducatifs.

\section{INTRODUCTION}

In countries such as Canada and the United States, learning English is essential for newly arrived adults to secure employment, participate in society, and even interact with their children and grandchildren. English language classes can also provide a connection to the culture in which newcomers find themselves (Schlusberg \& Mueller, 1995). In the province of British Columbia, free English as a Second Language (ESL) or English as an Additional Language (EAL) classes are offered through English Language Services for Adults (ELSA), a program funded by the Canadian government. While the language and cultural support provided to newcomers by ELSA and its instructors is invaluable, the program has limitations. For example, Canadian citizens and refugee claimants do not qualify to take ELSA classes within the Greater Vancouver and Greater Victoria areas. Moreover, there is a cap to the number of hours that a student may study with the ELSA program. Volunteer-facilitated language learning programs are therefore an important part of continued free ESL/EAL instruction for adults in British Columbia and elsewhere. Often funded by universities, social service organizations, and religious organizations, and usually conducted in informal settings such as libraries or places of worship, these volunteer-based programs provide free language support through both large- and small-group instruction and one-to-one tutoring. Since there is little research on volunteer-based adult ESL programs, let alone the training that their volunteers receive, this article addresses an identified gap by focusing on the training workshop offered by one such volunteer-based program, hosted by UBC's Learning Exchange in Vancouver, British Columbia.

Canadian Journal of University Continuing Education / Vol. 37, No. 2, fall 2011

Revue Canadienne de L'Éducation Permanente Universitaire / Vol. 37, No 2, automne 2011

http://ejournals.library.ualberta.calindex.php/cjuce-rcepu 


\section{Key Terms}

In UBC's Learning Exchange ESL Conversation Program Facilitator Training Workshop, as well as in this study, three groups are involved: the learners-adults who use English as a second or additional language; the trainers - UBC staff with EAL and/or adult education qualifications and expertise; and the volunteer facilitators. The use of the term facilitators rather than teachers has been a fundamentally important distinction since the early days of the training workshop. Although a few of the facilitators had pedagogical experience, or were multilingual and had experienced effective teaching techniques while learning languages, not being expected to be "a teacher" in the professional sense was both a relief and source of confidence, according to workshop trainers. In this article, we interchange the term facilitators with volunteers and volunteer facilitators.

\section{UBC'S LEARNING EXCHANGE ESL Conversation Program FAcilitator Training Workshop}

UBC's Learning Exchange opened in Vancouver's Downtown Eastside (DTES) in 2000 as a community-university engagement initiative (University of British Columbia, 2000). The DTES community is often described as Canada's poorest postal code; mental illness, crime, addictions, HIV/AIDS, prostitution, unemployment, and gentrification are a daily reality. Nevertheless, residents and patrons of the community often distinguish it as being vibrant and rich in lived experiences, the arts, volunteerism, social justice efforts, multicultural diversity, support, and acceptance.

When it opened, the Learning Exchange had two broad and complementary mandates: to provide a base for student volunteers and to offer free courses and volunteer opportunities to members of the DTES community. The approach of the Learning Exchange was (and continues to be) based on principles set out by John McKnight (1995): it aimed to identify assets in the marginalized community it serves and to build capacity there, rather than focus on problems and unintentionally created dependence (Petersen, 2006). The ESL Conversation Program Facilitator Training Workshop, developed from a graduate student's community project (Petersen, 2006), followed McKnight's model closely. In 2004, patrons of the Learning Exchange's drop-in program (where coffee and use of computers and the Internet were freely available) participated in a project in which a UBC graduate student documented their strengths and interests. The idea of undertaking ESL outreach to adult immigrants and refugees, with a focus on conversation, was consequently proposed.

In the beginning, training for volunteers consisted of a simple orientation and discussion of goals in an ESL conversation class, along with some modelling of technique by the graduate student who had initiated the project. The approach was deliberately informal and based to some extent on Paulo Freire's learning circles (Freire, 2000). Later, a grant enabled visits to these informal training circles by guest speakers who, for example, talked about immigrant experiences and language learning. Arising from this latter development, a formal arrangement for the training was made with UBC's English Language Institute (ELI), an organization on UBC's main campus offering short-term and long-term English language classes to international students. Led by ESL instructors from the ELI, a more structured training program for the volunteer facilitators was set up at the ELI with workshops held once a week, over a period of 12 weeks. Facilitators were provided with bus tickets to cover their travel to and from campus. ${ }^{1}$

Canadian Journal of University Continuing Education / Vol. 37, No. 2, fall 2011

Revue Canadienne de L'Éducation Permanente Universitaire / Vol. 37, No 2, automne 2011

http://ejournals.library.ualberta.calindex.php/cjuce-rcepu 
Key Strengths of an Innovative Volunteer Training Workshop

While attending the ESL Conversation Program Facilitator Training Workshop (hereafter referred to as the "training workshop" or the "workshop"), volunteers were simultaneously facilitating two conversation classes at the UBC Learning Exchange each week. The classes were divided into Level 1 (beginners), Level 2 (beginner-intermediate), and Level 3 (intermediate), categories loosely based on proficiency levels set out by Canadian Language Benchmarks (Pawlikowska-Smith, 2002). Placement of learners in a specific level was based on their oral skills during an informal interview. The learners attending the conversation classes represented a wide array of cultural backgrounds; senior learners with Chinese heritage, however, made up the largest percentage. Conversation classes were an hour and a half long, and class sizes were capped at a maximum of 10 learners. In the Level 1 and 2 classes, the topics discussed were drawn from commercially available ESL conversation textbooks. ${ }^{2}$ For the Level 3 classes, material had been developed by one of the trainers who led the workshop at the ELI. Because the ESL Conversation Program at the Learning Exchange was free, learners could register for only two classes a week. At registration, staff explained to learners that the conversation classes were led by volunteers and not paid teachers.

In the period covered by the research, the training workshops had relocated from UBC's main campus back to the Learning Exchange and were led by Mike, the Learning Exchange's ESL Program Coordinator, rather than an ELI instructor. Mike's background work experience included social work and mental health community care, as well as seven years of teaching ESL in a private language academy in Vancouver. Volunteers attended the training workshop (three hours each week) on Friday afternoons for three months, while also leading ESL conversation sessions at other points in the week. The volunteer facilitators and Mike met in a room around a table, and snacks and coffee were always available. The focus of the workshop included the fundamentals of facilitation, encouraging participation, classroom management, and learning theory. Time was also regularly set aside for reflection by volunteers on what was occurring in their conversation classes.

At the time of the research, the ESL Conversation Program at the Learning Exchange offered conversation classes to around 900 learners over four terms a year (waiting lists were not uncommon) and trained around 50 new facilitators each year (10 to 15 each term).

\section{Conceptual Framework}

We have drawn upon several different bodies of thought to inform the research goals, constructs for investigation, methods of investigation, analysis, and interpretation of findings.

\section{Asset-Based Community Development (ABCD)}

The first approach used to frame our study's principal goal, which was to identify the strengths of a community-based volunteer training workshop, was asset-based community development (ABCD). John Kretzmann and John L. McKnight conceived of ABCD as a community development philosophy (Kretzmann \& McKnight, 1993). Recognizing that shifts in the economy over the previous decades had devastated many neighbourhoods in older American cities by greatly limiting the opportunities for residents to find suitable employment and affordable housing, Kretzmann and McKnight proposed that these communities could rebuild themselves from the inside out by drawing on the assets of individuals and local organizations and institutions. $\mathrm{ABCD}$ is therefore often described as an approach that seeks to uncover and utilize the strengths within communities as a means for sustainable development (McKnight, 1995).

Canadian Journal of University Continuing Education / Vol. 37, No. 2, fall 2011

Revue Canadienne de L'Éducation Permanente Universitaire / Vol. 37, № 2, automne 2011

http://ejournals.library.ualberta.calindex.php/cjuce-rcepu 
Our research team appropriated $\mathrm{ABCD}$ as a research strategy, rather than as an approach to community development. Our decision reflected the documentation and early conversations with founders and staff of the training workshops, which made it clear that the workshop's overall aims had been framed in community development terms since its pilot in 2004 (Petersen, 2006). Hence, we agreed to focus on assets of the training workshop and its participants. In the formulation of our research question and the constructs, we have used the term asset as synonymous with the term strength.

Historically, the concept of describing or mapping of assets in communities can be linked to the philosophical and sociological concept of "social capital," a term used as long ago as 1916 by the philosopher John Dewey in his Democracy and Education, and in its most widely used sense by the social anthropologist Pierre Bourdieu in his Outline of a Theory of Practice (1977).

\section{Appreciative Inquiry (AI)}

Cooperrider and Srivastva (1987) developed this line of thought within the field of organizational development. In that seminal paper, traditional action research of social organizations is criticized for its reliance on deficiency-based theories such as turnover and intergroup conflict. The argument is made that these non-generative models channel researchers into a problemsolving approach where deficiencies and weaknesses within a particular organization are identified in order to "fix" them.

Organizations change in the direction in which they inquire. So an organization which inquires into problems will keep finding problems but an organization which attempts to appreciate what is best in itself will discover more and more that is good. It can then use these discoveries to build a new future where the best becomes more common. (Seel, 2008)

Its intellectual history can be linked to positive psychology, the scientific study of the strengths and virtues that enable individuals and communities to thrive (Seligman \& Pawelski, 2003) and to earlier psychological investigations of the constructs of self-efficacy and human agency (Bandura, 1989). When adapted as an educational research approach, as in the present study, AI is linked in certain ways to action research methods in education (Carr \& Kemmis, 1986), which share the goal of organizational and program improvement through research.

\section{Method}

The qualitative study was conducted over two terms at UBC's Learning Exchange between September 2009 and April 2010, with each term consisting of 10 training sessions. Volunteers attended the training workshop on Friday afternoons while also leading ESL conversation sessions at other points in the week. The guiding research question was "What are the perceived strengths of the ESL Conversation Program Facilitator Training Workshop?" Our second research question, which will not be addressed in this article, asked "How does the training workshop work as a community of practice?" This question refers to ideas by Lave and Wenger (1991), who viewed learning as a social process within a community.

\section{Participants}

The participants involved in this study can be classified into two groups. The first of the two groups consisted of four staff members (past and present) from the Learning Exchange who were involved in the training workshop, including two of the former trainers and the current trainer at the time of the study. The second group consisted of 14 volunteer facilitators in training (six during the first term and eight during the second). Six of the volunteer participants

Canadian Journal of University Continuing Education / Vol. 37, No. 2, fall 2011

Revue Canadienne de L'Éducation Permanente Universitaire / Vol. 37, No 2, automne 2011

http://ejournals.library.ualberta.calindex.php/cjuce-rcepu 
Key Strengths of an Innovative Volunteer Training Workshop

were women and eight were men; all were either residents of the DTES community or patrons of the community's various services and activities. Only new volunteers participated in the study during the first term, while a mix of new and returning volunteers participated during the second term. For a variety of reasons, most of the volunteers were unemployed at the time of the study. Ten of the 14 volunteer participants were not first-language speakers of English; their first languages included Mandarin, Cantonese, Tagalog, French, Japanese, and Russian. The ages of the facilitator participants ranged from 30 to 60, with most being in their 50 s. All the participants included in this study completed the 10-week training workshop. A few of the participants were attending the training workshop for a second time and had been facilitating conversation classes for at least a few terms.

In keeping with ethnographic techniques employed for this study, the researcher on site adopted the role of participant-researcher by attending and participating in the weekly training workshop along with the volunteer facilitators.

\section{Data Collection}

Three data types were collected from the volunteer facilitators during the training workshop: focus group reflective discussions, observations during the training workshop, and questionnaires. There were two focus group reflective discussions; the first was conducted at mid-term and the second at the end of term. Since the reflective component was already built into the workshop prior to the study, additional questions specifically addressing the goals of the study were combined with those regularly used in the workshop. For the mid-term reflections, participants were asked to complete statements such as "When I started, I felt ...." or "In the Friday workshop, I'd like to learn more about ..." (see complete list of statements in Appendix A). The end-of-term reflections consisted of several questions, such as "How would you describe the relationship between facilitators during the training workshop?" (see list of questions in Appendix B). Participants were provided with the statements and questions one week before the focus group sessions. The observations were made during each training workshop. Notes on the interactions between participants and on the exchanges of learning taking place were recorded in a journal by the participant-researcher. As well, notes were made on the kinds of assets participants were bringing to the table. The questionnaire was completed by participants several weeks before the end-of-term focus group discussion. The questionnaire was built around five themes: motivation of volunteers to participate (seven questions); personal contribution to others in the training session (three questions); benefits gained from other volunteers (three questions); benefits gained from trainers (five questions); and the role of UBC (five questions). These themes came from the conceptual framework, along with the specific questions we had for research.

Additionally, a semi-structured interview with the four staff members provided yet another layer of data, which included the perspectives of the trainers (see list of questions in Appendix C). All interviews and focus group discussions were audio-recorded and transcribed verbatim for analysis. Because of absenteeism, some participants were unable to provide data; 10 mid-term reflections, 12 questionnaires, and 11 final reflections were collected and analyzed.

\section{Analysis of Data}

Interview and focus group data were analyzed qualitatively following Miles and Huberman (1994), Bodgan and Biklen (1998), Merriam (1998), and Silverman (2000), using themes based on our research questions and theoretical conceptualization. The questionnaires were analyzed in the same way and used as complementary data.

Canadian Journal of University Continuing Education / Vol. 37, No. 2, fall 2011

Revue Canadienne de L'Éducation Permanente Universitaire / Vol. 37, No 2, automne 2011

http://ejournals.library.ualberta.calindex.php/cjuce-rcepu 
Key Strengths of an Innovative Volunteer Training Workshop

After multiple readings of the entire data set, a coding manual was initially developed that included 10 themes. Each theme was thoroughly defined and illustrated with samples drawn from the data. This coding manual was subsequently used for iterative data analyses, and after each iteration the codes were further refined until the following nine key themes were agreed upon by all research team members: motivation to join and participate; training approach; teacher/facilitator construct; assets of facilitators; confidence and capacity building; positive atmosphere; exchange of learning; transformation of self and learning; and involvement of the university. ${ }^{3}$ The unit of analysis decided upon was idea chunks in the data, either spoken consecutively by one participant or spoken by multiple participants. As explained earlier, the themes were drawn from the conceptual framework as well as from the specific research question. After this, the entire data set was divided among the research team, who first coded their data individually and then worked in pairs to compare their coding and reach a consensus. The coding manual was referred to when needed, but no substantial coding discrepancies were found between the pairs.

This qualitative analysis of the data resulted in the findings presented in the next section. In terms of validity, these findings are based on themes that appeared multiple times across the data.

\section{FINDINGS}

Our findings were fourfold. The first strength we identified was the workshop's training approach. Because it was organic and informal, it tapped into the concept of facilitating conversation rather than teaching concepts, and it modelled a positive, humorous, and supportive atmosphere. A second strength of the training workshop was its aim to build the confidence and capacity of the volunteer facilitators. A third strength was that the workshop recognized, valued, and drew upon the individual assets of the volunteers, which in turn generated and enhanced new kinds of learning. The fourth strength was the support received from the sponsoring university. In the following sections, we provide examples drawn from staff interviews, focus groups, and observation notes, to support the four findings. Whenever possible, we include the words of the participants as they were originally transcribed (without editing) so as to ensure that the voices and reflections of the participants are heard and appreciated.

\section{Training Approach}

All three trainers participating in the study highlighted that their approach during the training workshop was both organic and informal in the traditional sense. Laura, who was a graduate student at UBC when she initiated the ESL Conversation Program at the Learning Exchange in 2004, reflected on her approach to the training workshop:

I wanted to see it happen organically and how it would be with different facilitators. An expression of who they are in this kind of leadership role .... It [her training approach] was really unstructured. I was really basing it on Paulo Freire's sort of learning circles. ... . My approach was this really is your language class. And, um, these discussion questions are just here to help guide you. (interview, June 2010)

Here, an "organic" approach, as described by Laura, is understood as being part of a discussion and taking the lead from questions, comments, and experiences raised by the volunteer facilitators. By being open-minded, flexible, and comfortable with minimal predetermined (or imposed) structure during the training workshop, the trainers aimed to create a space where the experiences and thoughts of the volunteers could be shared and discussed comfortably.

Canadian Journal of University Continuing Education / Vol. 37, No. 2, fall 2011

Revue Canadienne de L'Éducation Permanente Universitaire / Vol. 37, No 2, automne 2011

http://ejournals.library.ualberta.calindex.php/cjuce-rcepu 
Key Strengths of an Innovative Volunteer Training Workshop

Another aspect contributing to the strength of the training approach was the emphasis placed on "facilitating" instead of "teaching" during the workshop. Mike, the current trainer at the time of the study, commented:

The workshops are all about demystifying this whole ESL thing. Sharing language is pretty human and natural. So we do that in the workshops. ... Again, the problems come when volunteers are thinking of themselves in this kind of teacher space and then they've got all these stereotypes about what it is to be a teacher. If you forget that and just act naturally, then it works. (interview, May 2010)

Over the course of the workshop, volunteers discussed the notion of not being ESL teachers but rather ESL conversation facilitators. When asked during the final focus group what they remembered as being important or useful during the training, one of the volunteers, Peter, replied:

Well, one thing I remember, Mike said we're not here to teach people stuff.

(focus group, April 2010)

These discussions can be traced back to the first training workshop, where Mike took the time to emphasize this particular point to the volunteers. In the second term, the volunteer participants often used the terminology of host (providing hospitality for a group) versus a star (solo performance), an analogy introduced by Mike on the first day of the workshop. Many volunteers shared that they were quite nervous when they first began attending the training, but once they realized that they were not expected to "teach" the learners, it helped them to relax.

The modelling of a positive, accepting, supportive, and humorous atmosphere by the trainers was another aspect contributing to the overall strength of the training approach. For instance, one of the volunteers, Tanya, was asked by Angelika (the participant-researcher) to share a highlight from the training workshop. Instead of answering the question, she began speaking off topic about earlier experiences in her life. Tanya differed from the majority of volunteers in that she often experienced extreme difficulty in concentrating during the workshop because of the medication she was taking. Yet rather than dismiss her response, Mike gently brought her back into the discussion, and his model of positively supporting Tanya and her contributions to the conversation was continued by other volunteer facilitators.

Tanya: I remember I was teaching in grade 7, grade 6 kids, English and math. They would listen to me and said repeat that. They would repeat saying ... [she continues with her description of her experience of the children repeating after her]

Mike: $\quad$ So when you were teaching the kids, everybody answered you?

Tanya: Yeah, I was, I wasn't on medication.

Mike: But in this class [the ESL conversation class] sometimes, when you said things, people didn't answer you.

Tanya: $\quad$ No, because I'm on medication since...

Mike: Well, I think it was your confidence.

Tanya: I'm on psychiatric pills since 18 years old ....

Mike: But like Keith was saying, you've become more confident.

Keith: Yeah.

Angelika: Yeah.

Canadian Journal of University Continuing Education / Vol. 37, No. 2, fall 2011

Revue Canadienne de L'Éducation Permanente Universitaire / Vol. 37, № 2, automne 2011

http://ejournals.library.ualberta.calindex.php/cjuce-rcepu 
Key Strengths of an Innovative Volunteer Training Workshop

Mike: $\quad$ So ...

Tanya: I think I woke up with this. . . [general comments, inaudible]

Lisa: $\quad$ And because you're interested, you're doing much, much better, Tanya, from when you started.

Tanya: I had more confidence when I was in grade 7, summer holidays I taught grade 6 and 7 math and English. I had more confidence.

Lisa: $\quad$ You think so?

Tanya: Yeah. Now I'm feeling fear of heights. When I was very young, I could jump from very high to very low. But in the pool, 11 feet, I can't jump, I feel fear. I don't want to jump. I can't jump.

Mike: That happens to me also. [general laughter]

Lisa: $\quad$ Yeah, I don't want to jump off a high spot either!

(focus group, December 2009)

\section{Confidence and Capacity Building}

The second strength of the training workshop at UBC's Learning Exchange was that, through developing facilitation skills and becoming part of a supportive group, volunteers developed confidence and capacity. Many of the volunteers came to the workshop having recently experienced significant challenges in their lives. In the training workshop and the ESL conversation classes, many found a space to begin to rebuild their confidence and sense of self-worth. For example, after Keith immigrated to Canada as an adult, his confidence was brought to a low point when he was bullied by co-workers at his place of employment in Vancouver. Keith shared how his participation in the training workshop and in the ESL conversation classes was a turning point for him:

I had some bad experience before, so I'm recovering you know, really well from that bad experience. I gain confidence in my language; at the same time, I'm happy that helping other people. That fact, I'm making a big difference in the life of others. Oh, thank you. (focus group, December 2009)

The training also supported confidence and capacity building by fulfilling the volunteer's initial motivations for participating. These motivations, as shared by the facilitator participants, included giving back to the community (as in the case of Keith), doing something useful, adding structure to their life, meeting new people, learning from other cultures, pursuing their interest in ESL learning, being challenged, improving their own English or employability opportunities, being involved with something related to UBC, and sharing their skills and knowledge. In both the questionnaires and the reflection discussions, participants repeatedly confirmed that their motivations to participate were being met or had been met. The training workshop also provided recognition of the volunteers' achievements through positive feedback from the trainer and peers. Finally, a certificate of completion and a letter of reference on UBC letterhead were presented to all volunteers who completed the training at a graduation celebration.

Canadian Journal of University Continuing Education / Vol. 37, No. 2, fall 2011

Revue Canadienne de L'Éducation Permanente Universitaire / Vol. 37, № 2, automne 2011

http://ejournals.library.ualberta.ca/index.php/cjuce-rcepu 


\section{Drawing on the Assets of the Volunteers}

The third strength of the workshop was that the assets of the volunteers were valued and drawn upon. Specifically, the trainers appreciated the volunteers' rich life experiences and acknowledged that these assets contributed significantly to the workshop and ESL conversation classes. As Mike explained:

So they're bringing that basic common sense, that kind of humanity, for what it's worth. I think empathy is another big thing they bring. (interview, May 2010)

A clear demonstration of this common sense and humanity occurred when Mike proposed a scenario - "What would you do if a learner came in late?" - which could be considered a tricky question to answer. Yet, instead of seeing this as a potential problem for the classroom, the participants unanimously agreed that you should welcome the latecomer and continue on with the conversation at hand. This response reflected their pragmatic and hospitable orientation.

Appreciation for the assets of the volunteers, paired with simultaneous confidence and capacity building, seemed to encourage exchanges of learning between participants. For example, when facilitators were prompted during the mid-term reflection to speak on what they were good at, the following exchange ensued:

Angelika: I'm good at...

Keith: Making people laugh, sharing ideas, feelings, and emotions.

Alice: $\quad$ This is one thing I have learned from Keith. (focus group, October 2010)

Keith, even though in the early stages of rebuilding his confidence, often felt comfortable enough during the workshop to share his thoughts, feelings, and humour with the other volunteers. Alice, in turn, viewed Keith's ability to share his experiences and feelings openly as a valuable asset in interpersonal communication.

The exchange of learning also extended to the trainers and the participant-researcher. For instance, Karen (one of the former trainers who delivered the workshop at UBC's ELI) and Angelika (participant-researcher) shared that their perspectives of the DTES and members of the community were altered by their interactions with the volunteers during the training workshop.

Karen: I also learned about the variety of people that are in the DTES. . . I hadn't really had anything to do with the DTES before.... There's people living down here because they're poor, and there's absolutely nothing else wrong with them, or needy about them. . . Y Yeah, which I never, never thought of that aspect before. I always thought it was where people go who have problems, or mental problems or whatever, drugs, alcohol. So that was kind of interesting.

Angelika: Yeah, I found, too, just my time participating in the training sessions, that it challenged a lot of my stereotypes. (interview, June 2010)

This excerpt provides a rich example of how the training allowed for a far-reaching exchange of learning by drawing upon the assets of facilitators to co-construct understanding.

\section{Support from the University}

Staff involved in the training workshop identified that the support from the university was a necessity in terms of providing qualified human resources, material resources, and physical space. Indeed, the workshop trainers were employees of UBC, and the meeting space for the workshop (three hours a week) and conversation classes (48 hours a week) was provided by UBC. Staff members also commented that volunteer facilitators and learners were both

Canadian Journal of University Continuing Education / Vol. 37, No. 2, fall 2011

Revue Canadienne de L'Éducation Permanente Universitaire / Vol. 37, № 2, automne 2011

http://ejournals.library.ualberta.calindex.php/cjuce-rсepu 
Key Strengths of an Innovative Volunteer Training Workshop

attracted to participating in the training workshop and conversation classes at the UBC Learning Exchange because of its widely recognized brand name and connection to the university. While the role played by UBC was not clearly identifiable to the volunteer facilitators, who for the most part assumed the connection was primarily financial, many spoke positively about the UBC staff they had interactions with. In the following conversation, several volunteers discuss the respect they have for their trainer, addressed by them as "Professor" Mike, whom they directly linked to university scholarship. Sam was attending the training workshop for the first time, while Jarod was a well-seasoned volunteer who had been facilitating conversation classes for several years.

Sam: The intellectual atmosphere. I really appreciate that and I feel there is a sense of scholarship - scholarly feeling - whenever Mike speaks about the topic. So I enjoy it, I like it.

Angelika: OK. Any other thoughts on the atmosphere?

Jarod: I think passion is an important element to have. I think it, you know, it translates. Once you have somebody in there who really cares about what he is doing - it just kinda pulls us to everybody else, you know. People get excited.

Liz: $\quad$ It's contagious.

Jarod: It really is. And you really need someone who has a sense that what they are doing is important in their own lives. And that comes out with Professor Mike. [general laughter] (focus group, April 2010)

The support provided by the university, however, was not without its tensions. The DTES community in Vancouver has been a hot spot for various research projects over the years. Many community members have grown cautious and even skeptical of university-based initiatives. Mike explained the tension that volunteers might have been feeling:

There's a tension for sure. UBC has got the cachet, it's a recognized program. It's not a rip-off, you're going to be well treated. It's got a professional reputation. But at the same time, this UBC maybe is going to be a bunch of intellectual snobs. (interview, May 2010)

It is important to note, however, that the facilitators who participated in the study did not raise concerns about such tensions. This may have been because the participants were a selfselecting sample of people who were experiencing success, in their own perception, in the training.

Awareness of this potential tension also prompted us to use the term evaluation as opposed to study when discussing the project with others. In the context of the Learning Exchange, evaluation is the more familiar term; participants understand it as describing a variation of the sort of informal formative evaluation already routinely done, to elicit their feedback on the program and how it might be improved. Study, on the other hand, might suggest academics putting aspects of the DTES under the microscope, which would not be welcome.

\section{Discussion}

Guided by the complementary frameworks of appreciative inquiry and asset-based community development, this study set out to identify the perceived strengths of the ESL Conversation Program Facilitator Training Workshop at UBC's Learning Exchange. To this end, the study design appreciated that the training workshop was succeeding because of assets already present within the community. The data collected, therefore, mapped the assets of the individual

Canadian Journal of University Continuing Education / Vol. 37, No. 2, fall 2011

Revue Canadienne de L'Éducation Permanente Universitaire / Vol. 37, No 2, automne 2011

http://ejournals.library.ualberta.calindex.php/cjuce-rcepu 
Key Strengths of an Innovative Volunteer Training Workshop

members, shed light on some aspects of the relationship between individual members and an external institution (UBC in this case), and yielded useful insights that point the way for growth.

First, the highly organic nature of the training approach (in the sense that we interpreted this term in "Findings" above) seemed to resonate positively with the volunteer facilitators, who repeatedly emphasized how comfortable they felt with the trainers' flexible pedagogy. In particular, the notion of guiding and assisting the volunteers in becoming successful "facilitators," rather than "teachers," contributed to modifying the volunteers' preconception that only professionally trained ESL educators have something to contribute. The notion of "facilitator" was not only discussed explicitly at length by the trainers and the facilitators, but was also co-constructed in the sense that it was modelled during the training sessions.

Second, the role of the trainer in helping the facilitators capitalize on their own strengths was shown to have a positive effect on the participants, not only on their further development of facilitation skills and pedagogical strategies but also, and perhaps most importantly, in providing them an opportunity to feel proud of their commitment and dedication to the DTES community.

Third, many of the participants came to the workshop having faced challenging experiences that positioned them variously as marginalized members of society. Yet in the training they found a place to create community, a sense of belonging that gave purpose to their life, and opportunities to contribute to society in meaningful, tangible ways. In the words of one participant: "This is like scaffolding to my life" (interview, Lisa, December 2009). We suggest that one of the main reasons for this success is that the workshop is based on the assumption that DTES residents have the capability to facilitate small-group ESL conversation classes. This belief resonates with Kretzmann and McKnight's (2003) suggestion:

Every single person has capacities, abilities and gifts. Living a good life depends on whether those capacities can be used, abilities expressed and gifts given. If they are, the person will be valued, feel powerful and well-connected to the people around them. And the community around the person will be more powerful because of the contribution the person is making. (p.1)

The findings also shed light on the personal growth of those involved in the study, revealing the dynamic, reciprocal nature of the exchange of learning. That is, not just those in training but also the trainers and the participant-researcher experienced shifts in their beliefs and perspectives.

Fourth, the university's multifaceted support was seen as fundamental in attracting volunteer facilitators as well as in implementing the training workshop. It was telling that 25 volunteer facilitators as well as several learners from the Learning Exchange attended the Centre for Intercultural Language Studies (CILS) Annual Research Symposium at UBC's main campus in May 2011. This yearly symposium is usually attended by faculty, graduate students, and language instructors from UBC and from other sister post-secondary institutions, public school systems, and government agencies. Such high attendance from the volunteer facilitators and learners would probably have been unlikely if they did not feel a high degree of comfort with UBC staff and a sense of belonging to the UBC community. This exemplifies Kretzmann and McKnight's (1993) claim that while communities have the capacity to rebuild themselves from the inside out by drawing on the assets of individuals and local organizations and institutes, they may also require support (in terms of funding and resources) from external institutions in order to operate.

Canadian Journal of University Continuing Education / Vol. 37, No. 2, fall 2011

Revue Canadienne de L'Éducation Permanente Universitaire / Vol. 37, No 2, automne 2011

http://ejournals.library.ualberta.calindex.php/cjuce-rcepu 


\section{Conclusion}

At present, the academic literature on volunteer-based ESL programs is small, and literature regarding the training for volunteers, particularly from marginalized communities, is, to our knowledge, equally scarce. Therefore, our study and its focus on one such training workshop address a significant gap. The ESL Conversation Program Facilitator Training Workshop at UBC's Learning Exchange is a grassroots program that evolved from informal consultation with the DTES community. And while training volunteers to facilitate ESL conversation classes is a clear objective of the program, its underlying mandate to build up the confidence and capacity of the participating volunteers by appreciating and drawing on their different assets is acknowledged by its founders as its most important goal and contribution toward the development of the DTES community.

To our knowledge, the theoretical frameworks of appreciative inquiry and asset-based community development have not yet been used to explore the assets of an ESL facilitator training workshop of this nature. Yet, as shown in this study, they proved to be promising strategies to assist in revealing the richness and diversity of social capital that the participants collectively bring to the program and in turn to the community. This project was a first attempt at describing the assets of the training workshop and the volunteers. It is part of the discovery step, where participants' stories, experiences, and reflections are documented through an informed design. A further step to follow involves taking up the findings of this study and capitalizing on the information yielded to continue to build, from the inside out, the strengths of the workshop.

This training workshop, as revealed in our study, has potential for replication and for serving as a blueprint for other low-key, grassroots programs of a similar nature. The content of the training, for example, has over time developed a focus more on learning and facilitating than on specifically English language learning; this broader focus could in turn be adopted by other programs that support volunteers as they facilitate a new skill or activity, such as in a computer training course or art class.

This study also revealed the importance of establishing research projects that involve members who are insiders of the communities under exploration; this, however, takes time. In our case, the participation of one of the trainers as a key collaborator in the study and of a researcher who spent significant time becoming acquainted with the community provided invaluable background information as well as a unique degree of access to participants.

Although the relationship between the sponsoring university and the volunteer facilitators in the training workshop was not without its tensions, our study revealed that the benefits of this partnership far outweighed any of its potentially negative aspects. For example, this research project contributed to the workshop's overall goals of demystifying the role of the university among the members of the community. We suggest that training workshops such as this constitute a promising way of enacting a community engagement strategy. Yet central to the success of such partnerships is the need to involve academics who are invested in the community, rather than "parachuting" in teams of academic experts. In this way, research can potentially contribute to community capacity building, rather than merely extracting knowledge.

Canadian Journal of University Continuing Education / Vol. 37, No. 2, fall 2011

Revue Canadienne de L'Éducation Permanente Universitaire / Vol. 37, № 2, automne 2011

http://ejournals.library.ualberta.calindex.php/cjuce-rcepu 


\section{ENDNOTES}

1. In 2007, the UBC ELI received an award of excellence for its work within the Learning Exchange's ESL Conversation Program Facilitator Training Workshop from the Canadian Association for University Continuing Education (CAUCE) and was recognized for having a "commendable vision to strengthen civil society" (Backhouse, 2007).

2. After the research, two committees of volunteer facilitators formed to develop their own topics and lessons for the Level 1 and Level 2 classes. These lessons are currently being used, and continue to be developed, by the volunteer facilitators in the ESL conversation classes at the Learning Exchange.

3. To ensure standardization, the research team of six coded the same excerpt of data individually and then compared their coding in a group meeting. This comparison and discussion resulted in some revisions to the coding manual, thus making it more precise and increasing coding reliability.

\section{REFERENCES}

Bandura, A. (1989). Human agency in social cognitive theory. American Psychologist, 14, 175-184.

Bogdan, R., \& Biklen, S. K. (1998). Qualitative research for education: An introduction to theory and methods (3rd ed.). Boston, MA: Allyn and Bacon.

Bourdieu, P. (1977). Outline of a theory of practice. Cambridge, United Kingdom: Cambridge University Press.

Carr, W., \& Kemmis, S. (1986). Becoming critical: Education, knowledge and action research. London, United Kingdom: Routledge.

Cooperrider, D., \& Srivastva, S. (1987). Appreciative inquiry in organizational life. In W. Passmore \& R. Woodman (Eds.), Research in organization change and development (Vol. 1, pp. 129-169). Greenwich, CT: JAI Press.

Dewey, J. (1916). Democracy and education. New York, NY: Macmillan.

Freire, P. (2000). Pedagogy of the oppressed: 30th anniversary edition. New York, NY: Continuum.

Kretzmann, J. P., \& McKnight, J. L. (1993). Building communities from the inside out: A path toward finding and mobilizing a community's assets. Chicago, IL: ACTA Publications.

Kretzmann, J., and McKnight, J. (2003). Introduction to asset-mapping. Retrieved from http://www.abcdinstitute.org/docs/abcd/IntroAssetMapping.pdf

Lave, J., and Wenger, E. (1991). Situated learning: Legitimate peripheral participation. Cambridge, United Kingdom: Cambridge University Press.

McKnight, J. (1995). The careless society: Community and its counterfeits. New York, NY: Basic Books.

Merriam, S. B. (1998). Qualitative research and case study applications in education (2nd ed.). San Francisco, CA: Jossey-Bass Publishers.

Miles, M. B., \& Huberman, A. M. (1994). Qualitative data analysis: An expanded sourcebook. Thousand Oaks, CA: Sage Publications.

Canadian Journal of University Continuing Education / Vol. 37, No. 2, fall 2011

Revue Canadienne de L'Éducation Permanente Universitaire / Vol. 37, № 2, automne 2011

http://ejournals.library.ualberta.ca/index.php/cjuce-rcepu 
Key Strengths of an Innovative Volunteer Training Workshop

Pawlikowska-Smith, G. (2002). Canadian Language Benchmarks 2000: Theoretical framework. Ottawa, ON: Centre for Canadian Language Benchmarks.

Petersen, M. (2006). Cultivating community: A story of cross-cultural learning and empowerment in the Downtown Eastside of Vancouver (Unpublished master's thesis). University of British Columbia. Retrieved from http://hdl.handle.net/2429/72

Schlusberg, P., \& Mueller, T. (1995). English as a Second Language in volunteer-based programs. Adjunct ERIC Clearinghouse for ESL Literacy Education, Washington, DC; National Clearinghouse for ESL Literacy Education, Washington, DC (ERIC Document Reproduction Service No. ED385172).

Seel, R. (2008). Introduction to Appreciative Inquiry. Retrieved from http://www.new-paradigm.co.uk/introduction_to_ai.htm

Seligman, M. E. P., \& Pawelski, J. O. (2003). Positive psychology: FAQs. Psychological Inquiry, 14, 159-163.

Silverman, D. (2000). Doing qualitative research: A practical handbook. Thousand Oaks, CA: Sage Publications.

University of British Columbia. (2000). A vision for UBC? A discussion paper. Retrieved from http://www.vision.ubc.ca/supp_docs/discussionpaper.html

Canadian Journal of University Continuing Education / Vol. 37, No. 2, fall 2011

Revue Canadienne de L'Éducation Permanente Universitaire / Vol. 37, № 2, automne 2011

http://ejournals.library.ualberta.calindex.php/cjuce-rcepu 


\section{Appendix A:}

\section{Mid-term reflection}

1. When I started, I felt ...

2. What I like most about the conversation sessions is ...

3. Some of the things I have found challenging are ...

4. I have learned ...

5. I need to work on ... .

6. I'm good at...

7. Some changes I've made to my facilitating approach are ...

8. In the Friday workshops, I'd like to learn more about ...

9. The good points of the workshops are...

10. Problems with the workshops are...

\section{Appendix B: \\ Questions for the end-of-term group discussion}

1. How did you hear about volunteering with the UBC Learning Exchange ESL Conversation Program?

2. What made you interested in volunteering as a conversation facilitator?

3. What, in general, did you like about facilitating at the Learning Exchange?

4. Please describe one experience that was a highlight for you, either in the classroom or in the training workshop.

5. What do you think of the teaching materials (e.g. text books, supplementary activity sheets)?

6. What would you change about the general organization of the program (e.g. times, classes, rooms, registration of students) if you could?

7. What went well with the training? What points do you remember as being most important or useful to facilitating classes?

8. What would you change, add to, or delete from the training?

9. How would you describe the atmosphere during the training workshops?

10. How would you describe the relationship between facilitators during the training workshops?

11. Overall, what have you learned from this volunteer experience?

12. As you understand it, what is UBC's role in the program? Do you think this role should be increased or decreased?

Canadian Journal of University Continuing Education / Vol. 37, No. 2, fall 2011

Revue Canadienne de L'Éducation Permanente Universitaire / Vol. 37, № 2, automne 2011

http://ejournals.library.ualberta.calindex.php/cjuce-rcepu 
Key Strengths of an Innovative Volunteer Training Workshop

\section{Appendix C: \\ Interview questions to the staff members}

1. Why do you think people volunteer as conversation facilitators at the Learning Exchange?

2. How would you describe your approach to training volunteer facilitators during the workshops?

3. What do you think are the strengths of the facilitator training workshop?

4. What are some of the challenges you face(d) with the facilitator training workshop?

5. Based on your experience, what personality traits, skills, and/or life experiences did the volunteers contribute during the training workshops?

6. Have you observed if the sharing of these traits, skills, and/or past experiences has been useful to other volunteers during the training workshops?

7. What have you learned from the volunteers during the training workshops?

8. As you understand it, what is UBC's role in the UBC Learning Exchange ESL program? Has this role changed over time? Do you think UBC should be more or less involved in the program? Why? And if yes, how?

9. How do you think the role of UBC in this program is perceived by the volunteer facilitators and learners?

10. Is there anything else you would like to share about the volunteers and the training workshops that you think may be helpful?

Canadian Journal of University Continuing Education / Vol. 37, No. 2, fall 2011

Revue Canadienne de L'Éducation Permanente Universitaire / Vol. 37, № 2, automne 2011

http://ejournals.library.ualberta.calindex.php/cjuce-rcepu 


\section{BIOGRAPHIES}

Angelika Sellick received her MA from the University of British Columbia in language and literacy education. She was a research assistant with the Centre for Intercultural Language Studies at UBC and currently works as a literacy outreach coordinator in Vancouver's Downtown Eastside.

Angelika Sellick détient une maîtrise ès arts de l'Université de la Colombie-Britannique en éducation des langues et de la littératie. Elle a été assistante de recherche au Centre pour les études linguistiques interculturelles de l'UBC et travaille actuellement comme coordinatrice communautaire en littératie dans le quartier Downtown Eastside de Vancouver.

Monique Bournot-Trites is an associate professor in the Department of Language and Literacy Education in the Faculty of Education at the University of British Columbia. She is the director of modern language education, and her research is on second-language acquisition and assessment.

Monique Bournot-Trites est professeure agrégée au département de didactique des langues et littératie de la faculté d'éducation de l'Université de la Colombie-Britannique. Elle est la directrice du programme de formation des maîtres en langues modernes, et sa recherche porte sur l'acquisition et l'évaluation de la langue seconde.

Ken Reeder is professor of language and literacy education at the University of British Columbia and serves as academic director of the UBC Ritsumeikan Academic Exchange Program. His research program deals with appropriate technologies for language teaching and learning, applied/educational linguistics, and first- and second-language acquisition.

Ken Reeder est professeur de langue et de littératie à l'Université de la ColombieBritannique et siège en tant que directeur académique du programme d'échanges universitaires UBC Ritsumeikan. Son programme de recherche traite des technologies appropriées pour l'enseignement et l'apprentissage des langues, la linguistique appliquée/éducative, et l'acquisition de la langue maternelle et seconde.

Andrew Scales is the academic director of the English Language Institute at the University of British Columbia Continuing Studies.

Andrew Scales est le directeur académique de l'Institut de langue anglaise à UBC Continuing Studies.

Mark Smith is community programs manager at the University of British Columbia Learning Exchange. His work experience includes managing community-living support for people moving out of institutional care in Scotland, and teaching ESL in Canada. Mark holds an MA from Glasgow University and is currently undertaking an MEd at Simon Fraser University.

Mark Smith est gestionnaire des programmes communautaires au Learning Exchange de l'Université de la Colombie-Britannique. Son expérience professionnelle inclut la gestion des services de soutien pour l'intégration communautaire de personnes qui quittent les soins institutionnels en Écosse, et l'enseignement de l'anglais langue seconde au Canada. Mark détient une maîtrise ès arts de l'Université de Glasgow et entreprend présentement une maîtrise en éducation à l'Université Simon Fraser.

Sandra Zappa-Hollman is a lecturer in the Department of Language and Literacy Education at the University of British Columbia. She works as academic writing coordinator in the UBC Ritsumeikan Academic Exchange Program.

Sandra Zappa-Hollman est chargée de cours au département de didactique des langues et de littératie de l'Université de la Colombie-Britannique. Elle travaille en tant que coordinatrice de la rédaction de travaux académiques pour le programme d'échanges universitaires UBC Ritsumeikan

Canadian Journal of University Continuing Education / Vol. 37, No. 2, fall 2011

Revue Canadienne de L'Éducation Permanente Universitaire / Vol. 37, № 2, automne 2011

http://ejournals.library.ualberta.calindex.php/cjuce-rcepu 